\title{
Needs-based Course Evaluation of Teaching and Learning English in Primary Education: A Case form a 2nd Grade Classroom
}

\author{
Deniz Şimşek \\ Bahcesehir University, IStanbul, Turkey \\ Enisa Mede ${ }^{2}$ \\ Bahçeşehir University, Istanbul, Turkey
}

\begin{abstract}
The purpose of this study is to investigate the attitudes and reflections of young learners as well as their teachers toward learning and teaching English in the 2nd grade classrooms. The study also attempts to find out whether the existing course meets the students' language and learning needs. A sample of 70 Turkish EFL students and 3 teachers enrolled participated in this research. The data were gathered through a scale and reflection drawing tasks administered to the students as well as collaborative diary written by the teachers. The findings revealed that the $2^{\text {nd }}$ grade students had positive attitudes toward learning English through playing games, watching videos and singing songs whereas they were less interested in writing, doing homework and studying course book. Besides, the teachers expressed their positive reflections focusing on student engagement and motivation as the key points while teaching English in their classes. Based on the gathered data, suggestions and implications are provided for the improvement of the existing $2^{\text {nd }}$ grade English course in the following academic year.
\end{abstract}

Submitted

24 May 2018

Revised

24 June 2018

Accepted

04 June 2018

Keywords: Language needs,

Attitudes,

Reflections,

Primary education,

EFL.

\section{Suggested Citation:}

Şimşek, D., \& Mede, E. (2017). Needs-based Course Evaluation of Teaching and Learning English in Primary Education: A Case form a 2nd Grade, International Journal of Academic Research in Education, 3(2), 13-27. DOI: 10.17985/ijare.424832

Deniz Şimşek, Bahçeşehir University, dsimsek2014@gmail.com

Enisa Mede, Bahçeşehir University, enisamede@gmail..com 


\section{INTRODUCTION}

Within the last two decades, English has become the lingua franca all over the world and the teaching of English is seen as more important and taken more seriously (Thomason, 2001; Hou, 2014). Because of the increasing awareness of globalization, the need of English proficiency has been growing rapidly. More energy, time and financial support are being given to the effort of preparing students in a growing and competitive environment. As a result, the introduction to the target language has started at early ages. Language curriculum, syllabi, courses and materials are designed based on the characteristics of learners. During this process, the language needs of learners as well as their attitudes toward learning English should be taken into consideration as well.

For successful language learning, most researchers emphasize the importance of acquiring a language at an early age and one of the factors to be successful in language learning is acquisition at a young age (Brewster, Ellis \& Girard, 2003; Brumfit, 1994). For instance, Brewster, Ellis (1992) believe that young children learn languages better and more easily. On this subject, Brumfit (1994) and Moon (2000) stated that acquisition of languages is possible at an early age because the brain is more adaptable before puberty and children have more positive attitudes to foreign languages and their cultures than adults. Freudenstein (1990) argues that children who begin to learn a foreign language at an early level seem to benefit from it more intellectually and be more culturally aware. In a similar vein, Karahan (2007) indicates that if the learners get exposed to the target language more, they will experience more effective and productive language learning. Harmer (2007) also explains through his work that young children learn faster and more effectively than any other age group. Therefore, as stated by Firat (2009), researchers have been investigating the features and psychology of young learners (YL) and the best ways of how to teach them while learning English.

Similar to the various educational contexts abroad, Turkey is currently facing enormous changes and educational medium is taking a new shape (İnal, 2006; Kırkgöz, 2007). Since Turkey has been drawing closer to entrance into the European Union, teaching English language has become a greater concern. This issue has also become the most important one for the Ministry of Education. As English Language curriculum has been investigated, various problems are discovered because there are still outdated approaches that are being implemented. There are new attempts done, especially in regard of the high standards of educational faculties and newly written teaching materials, however, these changes have not been enough for sufficient language development yet and still the majority of Turkish students are facing difficulty in learning the target language.

There are various aspects of teaching English as a second (L2) or foreign language (FL). During this process, curriculum and syllabus design are the two major aspects, which need to be considered deliberately. Krahnke (1987) stated in his work that these two aspects are the most ignored ones in language teaching. He added that the main decision in language teaching is the choice of a syllabus and it should be made by conscious decisions. Analyzing learners' needs and purposes of learning the target language is the starting point of designing syllabus (Nunan, 1988). The focus is shifted within each teaching unit at different points in the course. Thus, sometimes the focus can be on structures or on the functions that are determined by the needs of the language learners. A major language syllabus trend has been to use the information from and about learners. Therefore, one needs to be aware of students' language needs and their attitudes toward the language and design the syllabus to meet these needs and to reinforce their attitudes. 
Furthermore, Johnson (2009) and Nia, Abbaspour and Zare (2012) indicated that multi-dimensional approach is one of the best options as it allows us to put different syllabus specifications together and create a hybrid syllabus. Far (2008) underlined the core principle of a multi-dimensional syllabus is that there should be flexibility to change the central point of the teaching material while the course goes on. Besides, Johnson (2009) mentioned that multi-dimensional syllabus offer potential pedagogic advantage because of providing variety because the shift of focus changing at regular points.

To wrap up, as students are at the core of the learning process, the educational institutions should take into consideration their language and learning needs, attitudes, wants as well as necessities while choosing the syllabus and designing the language programs. As all types of syllabi have their merits and drawbacks, using a hybrid syllabus might be suggested as one of the more convenient and effective options to be administered in language classrooms.

\section{The Importance of Syllabus/Course Design in Language Learning and Teaching}

There has been a shift from teacher-centered classrooms to learner-centered ones. In recent approaches, learners are seen as active information receivers, rather than passive listeners. Therefore, the role of a teacher has changed from direct information giver, to the person who integrates learners to teaching procedure. To achieve this goal, courses and syllabi need to be designed based on the needs of the learners. In other words, having a syllabus makes a teacher's job easier but s/he should decide which type of syllabus is appropriate for the students by identifying their needs to design an effective language program (Şanal, 2016).

It is obvious that a syllabus provides control of the learning process by the institution and teachers, as well as, the learners during the language learning process. Odivilas (2015), for example, mentioned that the course plan or syllabus is a legally written contract between instructors and students in a college setting. More specifically, the syllabus binds the students to the plan of the course in order to be successful and it also binds the instructors to the plan too. Likewise, Lucier (2015) thought that the organization of learning experiences of the course and listing the planned activities for achieving the course, were possible by the syllabus. To exemplify, Blinne (2013) worked with her classes for developing a learning environment where life experiences are considered worthy of sharing and seeing all learners as teachers or researchers. In order to create a democratic learning process and environment, she wanted learners actively involved in selecting, changing and adapting course goals and the learning content. Hence, she designed the course syllabus by incorporating the learners into the process.

Bourke (2006) aimed to design a topic-based syllabus for young learners and his main focus was how to best design a syllabus and classwork material suitable for young learners. He emphasized the need for appropriate target setting and made the case for a topic-based/task-based syllabus, because a second language syllabus should reflect the world of children and facilitate the bringing acquisition into the classroom. He believed that the syllabus is much more than an inventory of teaching items, but also an approach to teaching or learning. Each syllabus has to consider the contextual variables and constraints and pay due regard to the principles of second language learning. Additionally, he suggested that language learning should relate to the child's world. According to him, children live in a world of fantasy and make-believe, a world of dragons and monsters, talking animals and alien beings, not a world of tenses, nouns or adjectives. Consequently, there are no schemas named grammar, lexis or discourse. A syllabus for young learners should contain topics of interest to children, all kinds of stories, games, fun, 
doing \& making activities, songs, chants and rhymes, pair and group work tasks, Big Books, materials from the Web, children's literature and any activity which allows acquisition in the classroom.

In a different study, Mudra (2016) investigated the beliefs toward learning English in higher education and whether any different exist in terms of gender. Although the obtained results did not reveal major discrepancy, there were some differences with particular items. For example, female students believe that good mathematical skills lead to poor understanding in English. Another difference was related to the extent of ultimate English comprehension. Based on these results, the existing English program was evaluated and suggestions were recommended.

Sardi (1997) investigated issues of needs-based language course/program design and focused on the question of how to integrate language needs of learners into syllabus content. By her research, she attempted to integrate into course design the results of a needs analysis that investigated the English language needs of Technical University students in Hungary in 1996. Four target groups participated in the study. They were the students, their EFL teachers, subject lecturers and representatives of companies all over Hungary. The analysis showed that there was a discrepancy between the present teaching and learning situation and the students' needs. The needs survey also allowed the researcher to identify learners' needs, which were translated into course design. Particularly, a syllabus and a methodological framework were proposed.

Hatta (2004) carried out a study about designing syllabus for young Japanese learners aged 8-9 years old. In his paper, he attempted to look at the general theory of syllabus design and an overview of syllabus types. Thirdly, the designing of the syllabuses for young learners were attempted along with the description of the target group of eight-to-nine year olds. The procedures of syllabus design were discussed with a special focus on the 8-9 year-old Japanese learners of English. Finally, he proposed a syllabus appropriate for the target group of learners.

Loukia (2006) suggested that stories can become every young learner's school time treasure. Within the context of English language teaching in primary schools in Greece through a compulsory course book (Fun Way series), the paper identified a mismatch between what is considered as good primary practice and what is realized in practice through the use of stories inside the course book. Loukia developed a parallel, story-based syllabus and emphasized that a story-based framework of teaching and learning can be a very powerful tool in the hands of a teacher. Students can be intrigued by a well-organized story session that allows them to explore many features of the language. He added that teachers want to make students autonomous and lifelong learners and need to make a large step towards this aim if they want to make their students learn consciously and assume responsibility for their learning.

Considering the English education in primary education various studies were conducted in Turkey as well (Gören, 2008, Şad, 2011; Şad \& Karamova, 2015). To begin with, Gören (2008) aimed to evaluate the teaching English to young learners' course in a Turkish state university's ELT department with reference to the new English language curriculum for primary education. Her descriptive study included two interviews and a questionnaire. One of the interviews was for the teachers of TEYL course at the university's ELT department and the other was for the English teachers at primary schools. The questionnaire was prepared for the 4th grade students at the department. The results of the research showed that TEYL course should be improved to meet the expectations of the teacher trainees. In another research, Şad (2011) investigated to what extent the Primary School English curriculum aims to improve the listening skills of young learners. The results revealed that the curriculum places great emphasis to the improvement of the reading ability ignoring the importance of the listening skill development. In another study, Şad and Karamova (2014) analysed, described and compared three cases including a non-native English teacher, a classroom teacher, and a native-speaker English teacher in terms 
of teaching English to young learners in general as well as teaching listening skills in 2nd grade Primary School English Curriculum. The data collected from observations, interviews and document analysis showed similarities and differences between three cases related to the medium of instruction, classroom atmosphere, instructional activities, activities towards improving four language skills (particularly the listening skill) and language areas, measurement and evaluation, and teachers' views in terms of the curriculum and course books. Considering teaching listening skill, the results of the multiple choice listening tests showed that the native and non-native English teachers were successful while teaching general English and also while developing the listening ability. To the contrary, the classroom teacher needed to improve his English proficiency as well as the pedagogical knowledge about teaching English to young learners.

Based on these overviews, it is obvious that needs assessment clarifies how and why students will need to use language in real-life as well as how teachers should teach language effectively Therefore, needs assessment should be the primary step to identify the needs of the students which will serve as a main guide to design a language course and also an overall curriculum.

\section{Purpose of the study}

The present study aims to investigate the attitudes and reflections of students as well as identify the reflections of teachers about learning and teaching English in $2^{\text {nd }}$ grade EFL classrooms. In accordance with the purpose, the following research questions were addressed:

1-What are the attitudes of $2^{\text {nd }}$ grade Turkish EFL students toward learning English?

2-What are the reflections of students about the $2^{\text {nd }}$ grade English course?

3 -What are the reflections of teachers about the $2^{\text {nd }}$ grade English course?

4-What suggestions can be provided for the improvement of the existing course?

\section{METHOD}

\section{Sample and Setting}

The present study was conducted at a $2^{\text {nd }}$ grade of a private k-12 school in Istanbul, Turkey. There are only three $2^{\text {nd }}$ grade classrooms where the students receive 18 hours of instruction per week. 12 hours are dedicated to main course which aim to improve the four language skills, grammatical structures and vocabulary knowledge of the students. The rest 4 hours are dedicated to the speaking club where students are engaged in role plays to improve their productive skills.

Specifically, the data were gathered from 70 students (33 girls and 37 boys) engaged in the $2^{\text {nd }}$ grade English program. Their age range is between 7 to 8 years old. Most of them started to learn English in kindergarten, so it can be said that they have 2-3 years of experience learning English. Apart from the students, 3 English teachers who are teaching $2^{\text {nd }}$ grade students also participated in this study. Their age range is between 29 to 36 years old and they have at least 5 years of teaching experience. One of the teachers is male while the other two are female. They all have their BA in the field of English language teaching as well as a CELTA certificate.

\section{Data Collection Techniques}

In this study, the data were collected through three different instruments; a scale and reflection drawing task administered to the $2^{\text {nd }}$ grade students, as well as, a collaborative diary written by the teachers. By doing so, the researcher aimed to seek convergence among students' attitudes, teachers' perceptions, reflections as well as their teaching practices. 
To begin with, a Smiley Face Language Attitude Scale was adapted from Çelik (2016) with an attempt to find out the language attitudes of the $2^{\text {nd }}$ grade English Language learners. The questionnaire consisted of two sections. The first one aimed to gather demographic information about the participants while the second one consisted of items regarding the students' attitudes about English lessons.

In addition, the participating students were asked to draw pictures that reflect their English lessons. They were given a sheet of paper, regular and colored pencils to make their drawings. According to Vygotsky (1962) forms of communication might have included symbols, algebraic systems, art, writing, diagrams and writing. He also mentioned that children would express their feelings by drawings or telling stories if they were not prepared to express themselves by traditional forms of writing. Brooks (2009) supported Vygotsky and indicated that drawings contain memory, experience, imagination and observation. Therefore, it requires the integration of these aspects and such activities to give children the opportunity to express their feelings, opinions and views, which is seldom possible to do through the words. Finally, apart from the pictures, the $2^{\text {nd }}$ graders were asked to write three Turkish sentences about their English lessons to get more in-depth information about their reflections toward English.

As the last data collection instrument of this study, 3 participating $2^{\text {nd }}$ grade EFL teachers were asked to write a collaborative diary about their classroom practices. According to Krishan and Lee (2002), a diary is a record of first-person observations of learning experiences over a period of time. For this reason, a teachers' diary may be an influential tool for getting reflections on the teaching styles, methods, needs, strengths and weaknesses. In line with this view, each participating teacher wrote one weekly entry about the general attitudes and engagement of the student in the lesson, as well as, their ideas about the $2^{\text {nd }}$ grade English program (lesson plans, objectives, materials and activities). The collaborative diary writing process lasted 7 weeks in total. Each entry was one paragraph long; therefore, the diary was around 11 pages in total.

\section{FINDINGS \& DISCUSSION}

The first question of this study attempted to investigate the attitudes of the 2nd grade Turkish EFL students towards learning English. With regards to this question, the Smiley Face Language Scale was administered to the $2^{\text {nd }}$ graders to find out their attitudes about their English classes. The analysis of the scale revealed that the $2^{\text {nd }}$ graders shared both positive and negative attitudes about certain tasks and activities about the English lesson (see Tables 1 and 2).

Table 1: Positive attitudes about English

\begin{tabular}{lll}
\hline Theme & Answers & $\%$ \\
\hline & Playing games & 75.7 \\
& Watching videos & 74.3 \\
Positive attitudes about English & Singing songs & 71.3 \\
& learning new words & 61.4 \\
& Listening to songs & 60.0 \\
\hline
\end{tabular}

To begin with, the results displayed in Table 1 proved that students had positive attitudes toward English. They particularly loved playing games, watching videos and singing songs. They also loved learning new words and listening to songs. 
Table 2: Negative attitudes about English

\begin{tabular}{lll}
\hline Theme & Answers & $\%$ \\
\hline \multirow{2}{*}{ Negative attitudes about English } & Doing homework & 72.0 \\
& Studying course books & 68.9 \\
& Writing & 66.4 \\
\hline
\end{tabular}

On the contrary, doing homework was the least favorite activity expressed by the participants. The possible reason for this finding might be the case that students are at the age of playing games in their spare time and do not like to spend their time by doing homework. Another reason behind this might be related to the content of homework being boring or difficult. This assumption can be supported by the study of Landing-Corretjer (2009) since it shows the $5^{\text {th }}$ and $6^{\text {th }}$ graders do not complete their homework because they find it too difficult, boring or not understandable.

Besides, the gathered findings also revealed that most of the students also held negative attitudes to the course books. A possible reason behind this finding might be related to the students' needs. This assumption can be supported by the study of Rahimi and Hassani (2011) as they believed the perfect book can be explained as a book, which suits the needs, abilities and interests of the learners and the teachers as well. Inal (2006) also shares the same idea, which is related to not having a perfect course book that meets the needs of all students, teachers and schools. At this point, it can be stated that teachers, students and administrators should be involved in the process of choosing and adapting a course book based on the students' needs, interests and attitudes.

Finally, the results indicated that writing was one of the least favorite activities among the students as well. A possible reason behind this might be that at this age, students improve their writing skills in their native language and L2 writing skills can be developed according to their L1 writing proficiency. One another reason might be that students generally do writing activities around the exercises in their course book. Since studying course book is one of the least favorite activities, this might be affecting their attitudes toward the skill "writing".

Based on the gathered findings, it can be inferred that the findings of the current study were in accordance with the research study of Karahan (2007) stating that having positive language attitudes will let students have positive orientation towards learning English.

On the other hand, the recent study displays differences between the study of Akça and Elkılıç (2008) who analyzed $4^{\text {th }}$ grade Turkish students' motivation and attitudes towards learning English through the medium of storytelling in a private school. Whereas the current study's results revealed that the most favorite activities for the students were playing games, watching videos and singing songs, the findings of their study proved that storytelling and grammar were perceived as an enjoyable English task by the majority of the participants. A possible reason for the differences might be related to the students' age. Since the participants of the present study are younger, they might enjoy fun activities more. This reason can be supported by Bourke (2006) because of the belief that children live in a world of fantasy, not in a world of grammatical rules and they do not have schemas related to grammar. 
Moreover, the second question in this research aimed to find out the reflections of students about the $2^{\text {nd }}$ grade English course. To answer this question, a reflection drawing task was administered to participating students. Furthermore, students were asked to write three sentences related to their English lessons.

To begin with, the reflections of students' drawings were grouped under positive and negative statements about learning English in the $2^{\text {nd }}$ grade classroom. The findings demonstrated that students mostly have positive reflections about learning English. The majority of the drawings were related to their English teacher, English lesson and about learning English and the mostly used positive statements were "I love my teacher", "I love English lesson" and "I love learning English" (see Appendix A).

Table 3: Students' Positive Reflections

\begin{tabular}{ll}
\hline & $f$ \\
\hline I love English lesson. & 20.3 \\
I love my teacher. & 14.0 \\
I love learning English. & 10.5 \\
Learning English is fun. & 5.2 \\
The songs are nice. & 5.2 \\
The activities are fun. & 5.2 \\
I play games with my teacher and friends. & 4.8 \\
I dance with my teacher and friends. & 4.8 \\
TOTAL & 70 \\
\hline
\end{tabular}

On the other hand, twenty-four of the $2^{\text {nd }}$ grade students dictated some negative comments in their drawing task. The mostly mentioned negative statements were "I don't want to do English homework", "I don't like English much" and "I don't like the English lesson much".

Table 4: Students' Negative Reflections

\begin{tabular}{ll}
\hline & $f$ \\
\hline I don't like English much. & 6.3 \\
I don't like my teacher much. & 2.4 \\
I don't like the English lesson much. & 6.3 \\
I don't want to do English homework. & 9.0 \\
TOTAL & 24 \\
\hline
\end{tabular}

Based on the reflection drawing task, it can be implied that the $2^{\text {nd }}$ grade students had mostly positive attitudes about English (see Appendix B). The majority of the participants indicated that they loved their teacher, English lesson and learning English. They also thought that learning English is amusing by singing, playing games and dancing which support their positive attitude toward English. These findings were 
parallel to the studies conducted by Karahan (2007), Gardner \& Lambert (1972) as well as Şad \& Karaova (2015) that displayed close relationships between the success of second/foreign language learning as well as motivation and attitude.

Finally, the third question aimed to find out the reflections of teachers about the $2^{\text {nd }}$ grade English course. To answer this question, reflections of the teachers were gathered from a collaborative diary. The collaborative diary consisted of five major themes: student engagement, motivation and attitudes, course content and English program. Firstly, the findings of student engagement theme proved that teachers believed that it was one of the key points in the teaching process for their classrooms. Secondly, the indications of the teachers regarding the students' motivation, were coherent with the students who had a lower proficiency of English and tended to get less motivated. In other words, students who love English are more motivated. Another reflection related to motivation, was the more the students felt relaxed and confident in the lesson, the more motivated they were. Lastly, the students were more extrinsically rather than intrinsically motivated. The results of teachers' collaborative diary were related to the study of Gass and Salinker (2008) in respect of Krashen's affective filter hypothesis showing that the learners, whose attitudes are not optimal, will seek less input and they will have a higher affective filter. For this reason, the input will not reach to Language Acquisition Device (LAD). Another similar finding in the study of Ellis (1992) stated that the learners who have positive attitudes gain their goals easier and become more successful than the ones who have negative attitudes.

Thirdly, collaborative diary entries revealed that most of the students have positive attitudes toward learning English. This finding is parallel with the study of Fathia et al. (2014) that shows their analysis about attitude being an essential component in language learning. They believed that both attitude and motivation have positive impacts on students and motivation can influence their attitudes towards language learning and achievement.

In addition, the course content was analyzed in order to get teachers reflections. The results revealed that all of the $2^{\text {nd }}$ grade teachers had different course content and subjects to cover while teaching English. Whereas all the teachers were contented about the course content of CLIL lessons, literacy and the main course lessons were criticized due to the books and materials currently being used. A reason behind this finding might be that CLIL lessons have more specific subjects when compared to the other lessons. Since the main objectives of the lesson are teaching Math and Science, it can be said that the program is around the subjects appropriate to the 2 nd graders. However, when literacy and main course lessons are considered, the subjects can differ. The needs and perceptions about students and teachers should be evaluated during the preparation of the course content and the selection of course books and materials. However, this is not the case in the current study. Therefore, the finding of the study shows differences between the study of Blinne (2013) in which students were asked to be involved actively in selecting, changing and adapting the course goals and the learning content. The students answered questions to find out their needs and interests and constructed a syllabus relevant to those needs and interests.

Lastly, the reflections of the teachers showed crucial findings related to the English program followed by the institution. Specifically, they exhibited that English program was too intensive and challenging both for the students and teachers. Besides, most teachers complained that they had to prepare extra materials and activities for their lessons.

Literacy classes are easy and boring since every 2 or 3 weeks we start a new story book and there aren't enough activities to do. When it comes to the book, again the students are not 
Şimşek, D. \& Mede, E..

happy with that because it is not colorful. Giving these reasons, it is kind of challenging for the teacher to provide the students with the appropriate materials and the teachers needs to come up with more fruitful and engaging activities. (Teacher 2 - Diary Entry, $24^{\text {th }}$ March, 2017)

Overall, the findings of current study revealed that while the teachers mostly had positive attitudes towards teaching English, some of them had certain problems with course content and the English program they follow.

I sometimes feel like the English program is too intensive for second graders. My observation has proved those students who start their school/kindergarten with the same institute, find it less challenging and more enjoyable. When it comes to new comers, they mostly feel like they are in the middle of nowhere during the first weeks/ months. (Teacher 2 - Diary Entry, $5^{\text {th }}$ April, 2017)

With reference to previous research, it was noted that while the overall findings of this study were consistent with previous research, they have some differences as well. In respect to having positive attitudes, the findings of this study are in accordance with the research of Reeves (2006) as well as Karabenick and Noda (2004) who stated that those researches were conducted in different contexts examining teacher's attitudes toward ELLs. For instance, the case for Reeves (2006) was the inclusion of ELLs in mainstream classrooms and for Karabenick and Noda (2004) teachers' beliefs, attitudes, practices and needs related to immigrant and refugee ELLS.

On the other hand, there are some differences between the findings of the current study and the studies of Mitchell (2016) and McKinney (2008). For instance, in the study of Mitchell (2016), a direct correlation was found between the years of experience and their attitudes regarding coursework modifications and significant differences in teachers' attitudes were observed among the teachers who had or had not received professional development. The case for the study of McKinney (2008) was teachers who felt they had adequate experience have more favorable attitudes toward ELLs. However, in this study no attitude difference was observed between the more experienced and less experienced teachers. The reason behind the findings might be related to the context, since those studies were conducted in USA with teachers who are teaching to ELLs students.

\section{CONCLUSION}

The results of this study indicated that most of the students had positive attitudes toward English, learning English, English lessons and teachers whereas they were negative about writing, doing homework and studying course book. Instead, their favorite activities are playing games, watching videos and singing songs. In addition, the teachers also shared positive reflections toward teaching English to the 2nd grade students apart from the problems they experienced with the content of the course and English program. As a result, modifying the course content and preparing a multidimensional/hybrid syllabus according to the needs and attitudes of the stakeholders is a crucial step to be taken for the $2^{\text {nd }}$ grade English classes.

To conclude, the present study provided valuable insight for future studies on teaching and learning English in young learners' classrooms. Overall, the gathered findings are significant for analyzing the attitudes, needs and reflections of students as well as teachers for designing and evaluating English courses in primary education. 


\section{References}

Akça, C., \& Elkılıç, G. (2008). Attitudes of the students studying at Kafkas University private primary EFL classroom towards storytelling and motivation. Journal of Language and Linguistic Studies, 4(1), 1-27.

Blinne, K. C. (2013). Start with the syllabus: Helping Learners learn through class content collaboration. College Teaching, 61, 41-43.

Bourke, J. M. (2006). Designing a topic-based syllabus for young learner, ELT Journal, 60(3), 279-286.

Brewster, J., Ellis, G., \& Girard, D. (2003). The primary English teacher's guide, London: Penguin English.

Brock, M. N., Yu, B., \& Wong, M. (1992). Collaborative diary-keeping: A tool for teacher development. TESL Reporter, 25(1), 19-25.

Brooks, M. (2009). What Vygotsky can teach us about young children drawing? International Art in Early Childhood Research Journal, 1(1), 1-13.

Brumfit, C., Moon, J., \& Tongue, R. (1994). Teaching English to children. London: Longman.

Çelik, Ö. (2016). The role of starting age to learn English in young learners' attitudes. International Journal of Language Academy, 4(1), 21-44.

Ellis, R. (1992). Second language acquisition \& language pedagogy. Avon: Multilingual Matters.

Far, M. M. (2008). An overview of syllabuses in English language teaching. Karen's Linguistics Issues.

Fatiha, M., Sliman, B., Mustapha, B., \& Yahia, M. (2014). Attitudes and motivations in learning English as a foreign language. International Journal of Arts and Sciences, 7(3), 117-128.

Fırat, A. (2009). A study on young learners' attitudes towards learning (Master's Thesis). Çukurova University, Adana, Turkey. Retrieved from http://library.cu.edu.tr/tezler/7607.pdf

Freudenstein, R. (1990), Issues and Problems in Primary Education, In C. Kennedy and J. Jarvis (Eds.), Ideas and Issues in Primary ELT. Hong Kong: Thomas Nelson and Sons Ltd. p.18-22.

Gardner, R. C., \& Lambert, W. C. (1972). Attitudes and motivation in second language learning. Rowley, MA: Newbury House.

Gass, M. S., \& Selinker L. (2008). Second language acquisition: An introductory course (3rd Edition). New York, Routledge.

Gören, S. Ç. (2008). An evaluation of the teaching English to young learners course in Gazi University ELT Department with reference to the new English language curriculum for primary education (Master's Thesis). The Institute of Educational Sciences of Gazi University, Ankara, Turkey.

Harmer, J. (2007), The Practice of English Language Teaching, 4th ed. England: Pearson Longman.

Hatta, G. (2004). Designing a syllabus for young Japanese learners aged 8-9 years old. Retrieved from: http://ir.lib.sugiyama-u.ac.jp/dspace/bitstream/123456789/118/1/\%E4\%BA\%BA11hatta.pdf

Inal, B. (2006). Coursebook selection process and some of the most important criteria to be taken into consideration in foreign language teaching. Journal of Arts and Sciences, 5, 19-29. Retrieved from http://jas.cankaya.edu.tr/

Johnson, K. (2009). Foreign language syllabus design. In K. Knapp \& B. Seidlhofer (Eds.), Handbook of foreign language communication and learning (pp.309-340). Berlin: Mouton de Gruyter.

Karabenick, S. A., \& Noda, P. A. C. (2004). Teachers' beliefs and attitudes toward English language learners. Bilingual Research Journal, 28(1), 55-75.

Karahan, F. (2007). Language attitudes of Turkish students towards the English language and its use in Turkish context. Journal of Arts and Sciences, 7, 73-87.

Krahnke, K. (1987). Approaches to syllabus design for foreign language learning. Englewood Cliff, NJ: Prentice Hall Regents.

Kırkgöz, Y. (2007). English language teaching in Turkey: Policy changes and their implementations. RELC Journal, 38(2), 216-228. doi: 10.1177/0033688207079696

Kuhn, T. (1970). S. 1962. The structure of scientific revolutions. Chicago: The University of Chicago Press. 
Landing-Corretjer, G. (2009). Listen to Me! An Exploration of the Students Voices Regarding Homework (Doctoral Dissertation). Retrieved from https://eric.ed.gov/?id=ED508264

Loukia, N. (2006). Teaching young learners through stories: The development of a handy parallel syllabus. The Reading Matrix, 6(1), 25-40.

Lucier, K. L. (2015). What is a syllabus? Retrieved from collegelife.about.com/od/academiclife/f/What-IsA-Syllabus.htm?utm_term

McKinney, R. W. (2008). Teachers attitudes toward English language learners (Doctoral dissertation). Retrieved from http://trace.tennessee.edu/cgi/viewcontent.cgi?article=1640\&context=utk graddiss

Mitchell, S. (2016). Relationships Among Teachers' Attitudes, Behaviors Toward English Language Learners, Experience, and Training (Doctoral dissertation). Retrieved from http://scholarworks.waldenu.edu/cgi/viewcontent.cgi?article=3667\&context=dissertations

Moon, J. (2000). Children Learning English, Hong Kong: Macmillan Publishers Limited.

Mudra, Heri. (2016). Prospective EFL Teachers`Beliefs about Language Learning and Gender Differences in a Higher Education Context, International Journal of Academic Research in Education, 2(1), 42- 50. DOI: 10.17985/ijare.13474

Nia, M. R., Abbaspour, E., \& Zare J. (2012). A critical review of recent trends in second language syllabus design and curriculum development. International Journal of Research Studies in Language Learning, 2(2), 63-82

Nunan, D. (1988). Syllabus Design. Oxford: Oxford University Press.

Nunan, D. (1989). Understanding Language Classrooms: A Guide for Teacher-Initiated Action. Englewood Cliffs, NJ: Prentice-Hall.

Odivilas, H. A. (2015). Syllabi preparation and utilization in college teaching. European Scientific Journal, 11(7), 483-503.

Rahimi, M., \& Hassani, M. (2011). Attitude towards EFL textbooks as a predictor of attitude toward learning English as a foreign language. Journal of Procedia-Social BehavioralSciences, 31, 6672.

Reeves, J. R. (2006). Secondary teachers' attitudes toward including English-language learners in mainstream classrooms. Journal of Educational Research, 99(3), 131-142.

Sardi, C. (1997). Needs-based syllabus design for students of English in Hungarian technical universities. ASP, 15-18, 1-12.

Şad, S.N. (2011). Ilköğretim birinci kademe ingilizce öğretim programının çocuklara yabancı dil öğretiminin duyuşsal hedeflerini gerçekleştirme düzeyi. Yayımlanmamış Doktora Tezi, İnönü Üniversitesi, Malatya.

Şad, S.N. \& Karaova, M. (2015). Illkokul ikinci sınıf ingilizce dersi bağlamında dinleme becerisi öğretimi: Bir durum çalışması. Eğitimde Nitel Araştırmalar Dergisi - Journal of Qualitative Research in Education, 3(2), 66-95.[Online]www.enadonline.com. doi:10.14689/issn.2148-2624.1.3c2s4m

Şanal, F. (2016). Syllabus Design. Journal of Turkish Language and Literature, 2(3), 187-192.

Vygotsky, L. S. (1962). Thought and language. Cambridge, MA: MIT Press.

Appendix A: Students' Positive Reflection Drawings

Drawing 1: Love of English teacher, English lesson and English 


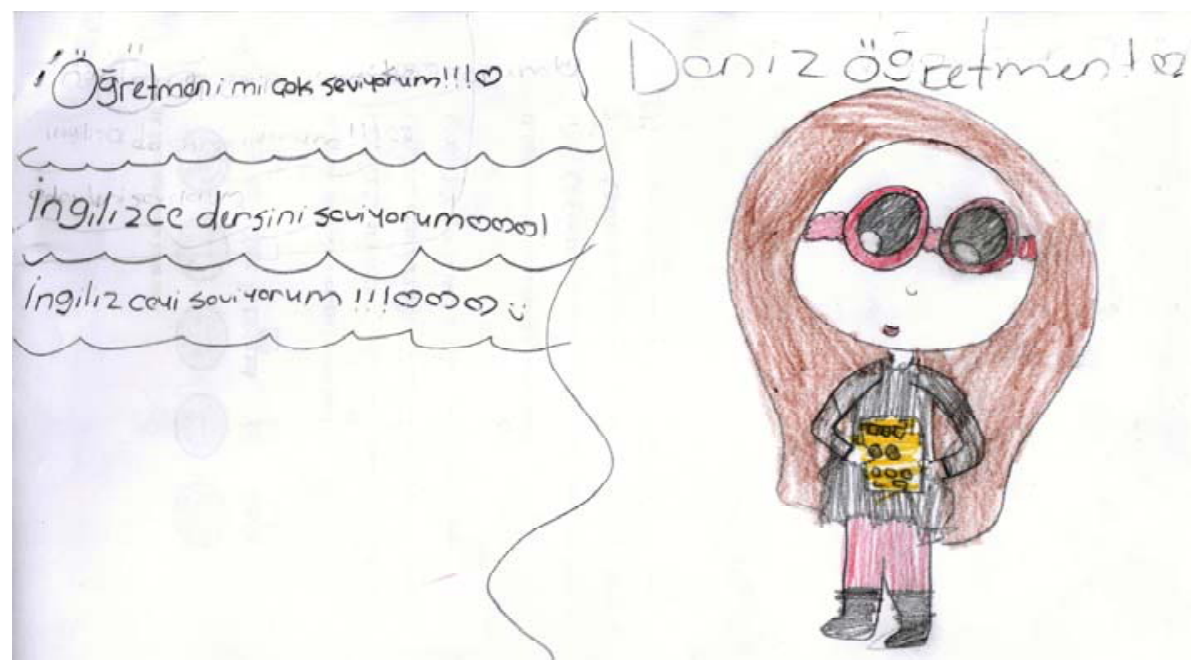

Drawing 2: Fun of learning English, listening to songs and doing activities

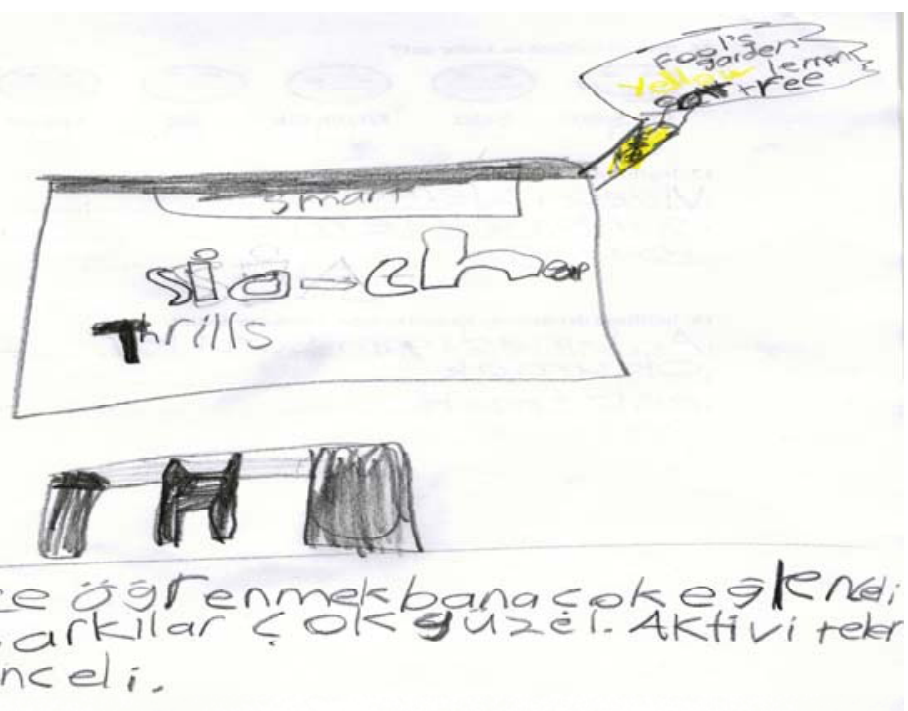

Drawing 3: Play games and dance with my teacher and friends 

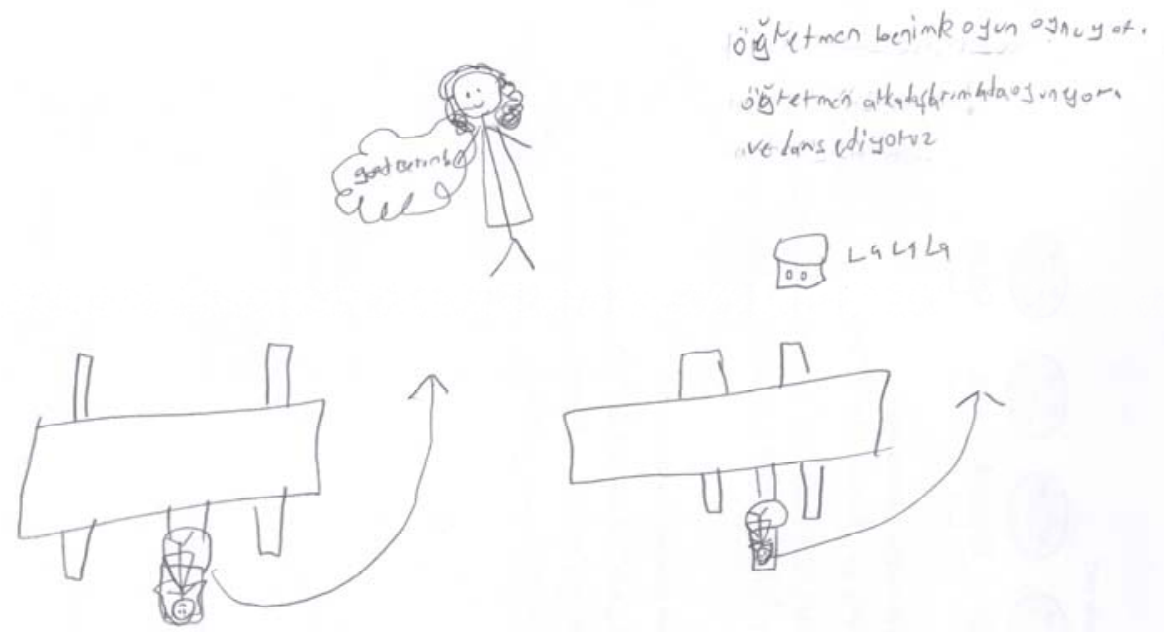

Appendix B: Students' Negative Reflection Drawings

Drawing 4: Don't like English, English teacher and English lesson

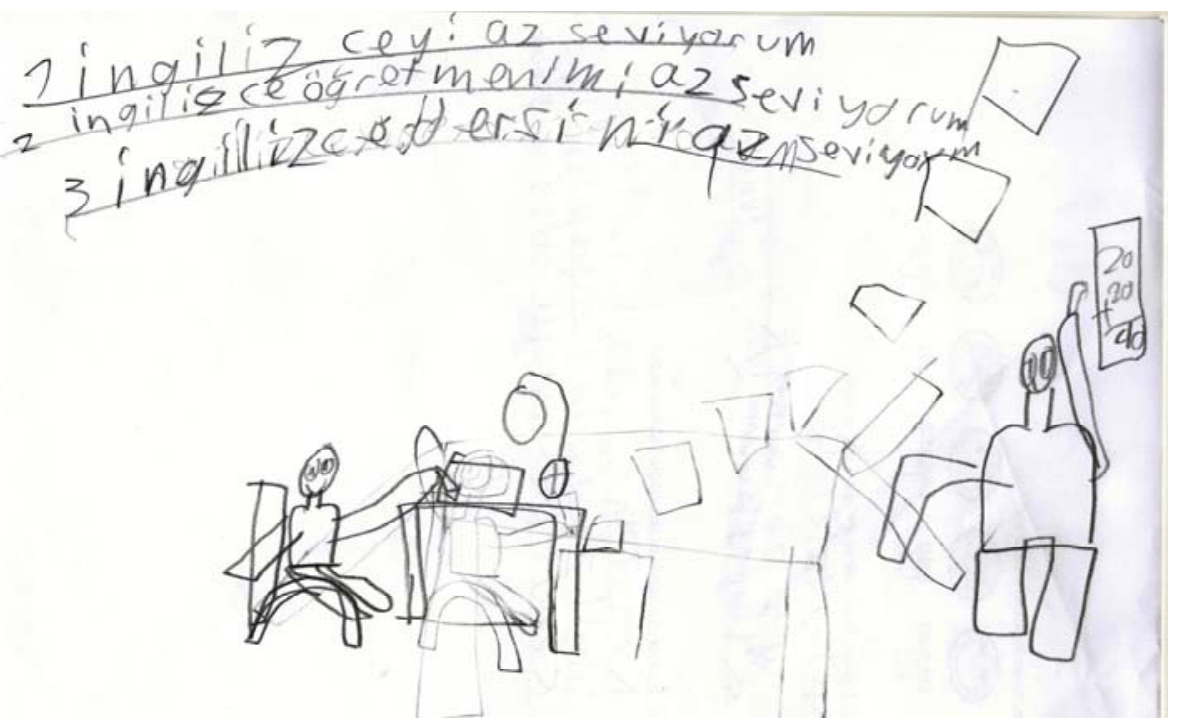

Drawing 5: Don't like doing English homework 
Tingilizce ádeu sapmak istemisoum $>$

3. ingilizce Ẽogetmenterimi sevigorcm

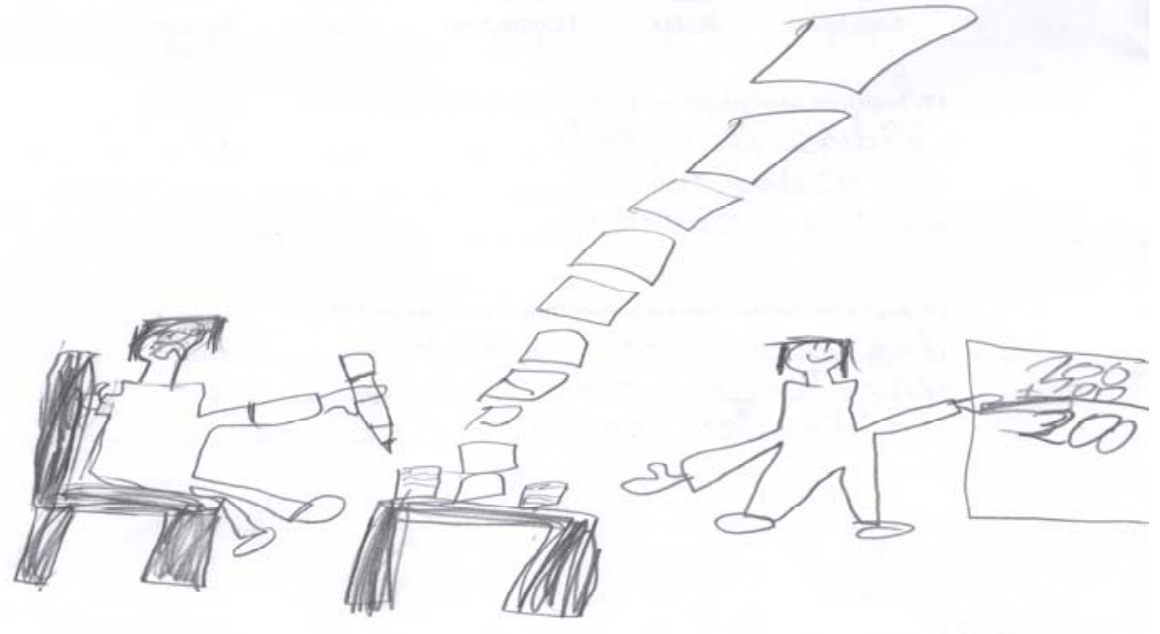

